\title{
Validation and translation of the Hungarian version of the Female Sexual Function Index (FSFI-H)
}

\author{
Márta Hock $^{1}$ • Nelli Farkas ${ }^{2}$ - István Tiringer ${ }^{3}$ - Stefánia Gitta ${ }^{1}$ • Zoltán Németh ${ }^{4}$ • Bálint Farkas ${ }^{5,6}$
}

Received: 15 April 2019 / Accepted: 10 July 2019/Published online: 29 July 2019

(C) The Author(s) 2019

\begin{abstract}
Introduction and hypothesis The Female Sexual Function Index (FSFI) has been used for clinical and research purposes in many countries. The aim of this study was to translate, adapt and perform a psychometric validation of a Hungarian version of the FSFI. Methods The FSFI was translated into Hungarian, and its precision was ascertained through reverse translation by an expert team. As a first step, 40 volunteers participated in an evaluation of the test-retest reliability of the Hungarian version over a 2week period. After that, 418 (331 control and 87 with pelvic organ prolapse) women who had been in a stable sexual relationship in the previous 4 weeks participated in the study. The data were summarized using descriptive statistics. The structure validity was examined by confirmatory factor analysis, with which we tested the hypothesized original factor structure, using maximum likelihood model estimation. We calculated the Comparative Fit Index (CFI), root mean square error of approximation (RMSEA), standardized root mean residual and Akaike information criterion (AIC). To test the internal consistency, Cronbach's alpha coefficients of the full scale were determined. Spearman's rank correlation was used for testing divergent validity and MannWhitney U-test for examining discriminant validity.

Results The FSFI was easily understandable and acceptable as well as capable of adequately evaluating and measuring various aspects of female sexual functioning. A high degree of internal consistency was demonstrated by the Cronbach's alpha value (0.963).

Conclusion The FSFI Hungarian version is a valid tool that measures the same functioning as the original English questionnaire.
\end{abstract}

Keywords FSFI $\cdot$ FSFI-H $\cdot$ Hungarian language adaptation $\cdot$ Sexual functioning $\cdot$ Validation

The abstract of the manuscript has been submitted for presentation at the 2019 Hungarian Continence Society's Scientific Meeting, held from 2-3 May at Pecs, Hungary.

Bálint Farkas

dr.balint.farkas@gmail.com

1 Institute of Physiotherapy and Sport Sciences, Faculty of Health Sciences, University of Pécs, Pécs, Hungary

2 University of Pécs, Institute of Bioanalysis, Pécs, Hungary

3 Institute of Behavioral Sciences, Medical School University of Pécs, Pécs, Hungary

4 Department of Gynecology, Hospital St. John of God, Vienna, Austria

5 Member of the MTA-PTE Human Reproduction Scientific Research Group, Hungarian Academy of Sciences (MTA), Budapest, Hungary

6 Department of Obstetrics and Gynecology, University of Pécs, 17 Édesanyák str., Pécs H-7624, Hungary

\section{Introduction}

Several benign and malignant gynecologic diseases have negative impacts on different segments of life, which may lead to sexual dysfunction. Sexual dysfunction can arise from other physical, social and psychologic factors as well [1]. These may cause problems during any phase of the sexual response cycle, preventing the individual from experiencing satisfaction during sexual activity. The prevalence of female sexual dysfunction (FSD) varies worldwide between 8 and 75\% [2-7]. In Hungary, only a small number of women seek professional help. These patients usually meet gynecologists as a primary physician, and then their treatment includes psychologists or sexologists; therefore, outpatient gynecologic counseling provides an important setting for conducting research, diagnosis and treatment of FSD [8]. The Female Sexual Function Index (FSFI) was designed to evaluate sexual function in a general population. The translation and validation of the FSFI 
allow the questionnaire to be applied in daily clinical practice, for research purposes and to estimate women's sexual function. The aim of the study was to adapt the FSFI questionnaire and to assess the reliability and validity of the Hungarian version among sexually active women.

\section{Materials and methods}

Women aged between 18 and 77, who had been sexually active and in a stable relationship for at least 4 weeks prior to the study, were recruited as volunteers in the current crosssectional study design. The majority of the participants had high school or university diplomas. Participants $(n=331)$ were healthy university students (Institute of Physiotherapy and Sport Sciences, Faculty of Health Sciences, University of Pécs). After a short personal interview focusing on the general health conditions and medical history (carried out by $\mathrm{MH}$ and $\mathrm{SG}$ ), the participants filled out online questionnaires. The exclusion criteria were concurrent sexually transmitted diseases (STD), prior or current malignancy, neurologic and psychiatric diseases (depression, schizophrenia, mental disabilities), severe somatic diseases, e.g., thyroid dysfunction, liver dysfunction, unstable coronary heart disease, addiction to psychoactive substances and/or alcohol, use of medications affecting sexual function (antipsychotics, antidepressants, antihistamines, benzodiazepines), pregnancy or being within 3 months postpartum, and illiteracy. The subjects were informed that their participation in the survey was anonymous and completely voluntary. This study was approved by the Institutional Review Board of the Faculty of Medicine, University of Pécs, in 2017 (no. 6920).

\section{FSFI}

The FSFI is a 19-item self-report questionnaire of female sexual functioning [9] consisting of six dimensions: desire (Q1, 2), arousal $(\mathrm{Q} 3,4,5,6)$, lubrication $(\mathrm{Q} 7,8,9,10)$, orgasm (Q11, 12, 13), satisfaction (Q14, 15, 16) and pain (Q17, 18, 19). The FSFI assesses sexual functioning over the past 4 weeks. The subscale scores range from 1 to 5 for items 1 , 2, 15 and 16. For all other items, the range was from 0 to 5 with the supplementary option "no sexual activity." The fullscale score ranges from 2.0 to 36.0 , where the higher score is associated with less severity of sexual dysfunction. The questionnaire showed a high degree of internal consistency (Cronbach's $\alpha$ values $\geq 0.82$ ) and high test-retest reliability for each domain (Spearman's rho $=0.79-0.86$ ). It has been successfully cross-validated, and a diagnostic cutoff score of 26.55 has been determined for classification of total FSD [10].

\section{Short form 36 (SF-36) survey}

The SF-36 measures health-related quality of life (QoL) across eight domains, which can be summarized as physical and mental health. The eight domains are as follows: physical functioning (10 items; Cronbach's $\alpha$ 0.93); role limitations due to physical health problems (4 items, Cronbach's $\alpha$ 0.84 ); role limitations due to emotional problems ( 3 items; Cronbach's $\alpha 0.83$ ); energy and vitality (4 items; Cronbach's $\alpha$ 0.86); mental health (5 items; Cronbach's $\alpha$ 0.90); social functioning ( 2 items; Cronbach's $\alpha 0.85$ ); bodily pain (2 items; Cronbach's $\alpha$ 0.78); general health (5 items; Cronbach's $\alpha$ 0.78). These scores are transformed into a domain score ranging from 0 to 100 , with a higher score representing higher levels of health-related QoL $[11,12]$. The four domain scores are averaged to a physical component score (PCS), and four other domain scores are averaged to a mental component score (MCS). An additional item with health change is not integrated into the PCS or MCS scores [13]. The Hungarian adaptation of the questionnaire and the determination of normal values were carried out by Czimbalmos et al. [14]. The SF-36 was completed at the same time as the FSFI-H for comparison.

\section{Translation of the FSFI into Hungarian (FSFI-H)}

The linguistic validation was carried out in accordance with the guidelines of linguistic validation processes [15]. The original FSFI was translated from English into Hungarian by two physicians, who are fluent in both English and Hungarian (version 1). The back translation of the FSFI-H into the original language was carried out by an independent bilingual investigator and was reviewed by the author to obtain a reliable translation (version 2). The translation was further reviewed by a ten-member expert committee, including gynecology specialists, PhD students, health sciences university teachers and behavioral science specialists, to achieve a reliable Hungarian version of the FSFI questionnaire (version 3). Then, a face-to-face interview was also conducted with women to check for any difficulties in understanding and interpreting the questions. No major difficulties were noted.

\section{Divergent validity}

Since no validated Hungarian questionnaires that measure the same context as the FSFI are available, the SF-36 questionnaire, a self-evaluated global quality-of-life measure, was applied as a benchmark.

\section{Discriminant validity}

To examine whether the Hungarian version of the FSFI can detect differences between a general/healthy population and a 
clinical population, we used retrospective data of a group of women with pelvic organ prolapse (POP), which is known to be correlated with decreased sexual quality of life because of the altered genital anatomy, decreased lubrication, and involuntary intracoital urine or fecal incontinence [16]. Patients $(n=87)$ were diagnosed in a urogynecologic outpatient clinic (Györ, Hungary). All patients provided written informed consent and volunteered to be included. All women had $\geq$ stage 2 POP of the anterior, middle or posterior compartment, or a combination of them. All reported a sensation of a bulge in the vagina with or without symptoms of urinary, bowel or sexual dysfunction. (All methods, definitions and units conform to the standards set by the International Urogynecological Association and the International Continence Society, except where specifically noted [17].)

\section{Test-retest reliability}

The final approved version was pretested in a pilot study on 40 women who were sexually active in a stable relationship 6 months prior to the study. The participants completed the same questionnaire twice with a 2 -week interval. During the first visit, we conducted a face-to-face interview and collected demographic data. Finally, the test-retest correlations were evaluated by applying Spearman's rank correlations and Bland-Altman plots between individual domains as well as in the full scales of the FSFI-H.

\section{Statistical analysis}

The data were summarized using descriptive statistics. The structure validity was examined by confirmatory factor analysis (CFA), with which we tested the hypothesized original factor structure, using maximum likelihood model estimation (Fig. 1). To determine which model had a better fit to our data, we compared generally offered fit indexes [Comparative Fit Index (CFI), root mean square error of approximation (RMSEA) and standardized root mean residual (SRMR)]. Acceptable values of the CFI are $>0.95$, of the RMSEA $<0.08$ and of the SRMR $<$ 0.11 [18]. Additionally, on the basis of the Akaike information criterion (AIC), the six- and five-factor structures were compared considering which had a better fit to our data set [19]. To test the internal consistency, Cronbach's alpha coefficients were determined. Spearman's rank correlation was used for testing divergent validity and the Mann-Whitney U-test for examining discriminant validity [20]. CFA was performed using AMOS (version 5); all other analyses were carried out with the IBM-SPSS version 25 software package. The results were considered significant if $p<0.05$.

\section{Results}

A total of 418 women were enrolled in the current study; 331 constituted the general/control group, with a mean age of $33.58 \pm 8.94$ years. (The majority, $47 \%$ of the participants, had high school or university diplomas, and $71.9 \%$ lived in urban areas.)

Eighty-seven women with pelvic organ prolapse (POP) comprised the clinical group, with a mean age of $47.86 \pm$ 12.27 years (POP stage II to IV, 64.5\%, $17.5 \%$ and 1\%, respectively), which was used for the discriminant validity.

\section{Structure validity}

Confirmatory factor analysis is a tool to verify a given theoretically based factor structure. Previous studies showed either a six- or five-factor structure in the case of FSFI: desire, arousal, orgasm, lubrication, pain, satisfaction (desire and arousal constitute a unique factor in the five-factor model) [21]. We analyzed the five- and six-factor models, and the six-factor model showed an acceptable $[\mathrm{CFI}=0.957, \mathrm{RMSEA}=0.76$ (CI: 0.66-0.85), SRMR $=0.514, \mathrm{AIC}=439.1]$ and superior fit compared with the five-factor model $[\mathrm{CFI}=0.949$, RMSEA $=0.81$ (CI: 0.72-0.09), SRMR =0.57, $\mathrm{AIC}=$ 505.1]. All factors except desire had acceptable standardized regression weights (range 0.644-0.942). The answers to the first item about the frequency of desire were different from the answers given to the second item about the level of desire. Spearman's rho between item 1 and 2 was only 0.187 ( $p=$ $0.001)$. Correlations among factors were high $(0.484-0.872)$.

\section{Reliability}

Cronbach's $\alpha$ coefficients were determined for the total and domain scores of the FSFI-H, which were high. In the subscales, they ranged from 0.423 to 0.981 . The coefficient was 0.963 for the full scale. The total FSFI domain scores obtained from the enrolled women are presented in Table 1.

\section{Divergent validity}

No significant correlations between the results of the FSFI-H and SF-36 were found with Spearman's rank correlation analyses among either the subscales or the total scores.

\section{Discriminant validity}

To establish differences between the control and POP patient group, the total and subscale scores of both groups were compared. In the analysis we used an age-matched group (45 \pm 5 years) from the original general control group. The results showed significant differences in the case of arousal, lubrication, orgasm, satisfaction and the total score. (Table 2). 
Fig. 1 The six-factor model with factor loadings, correlations between factors and error terms

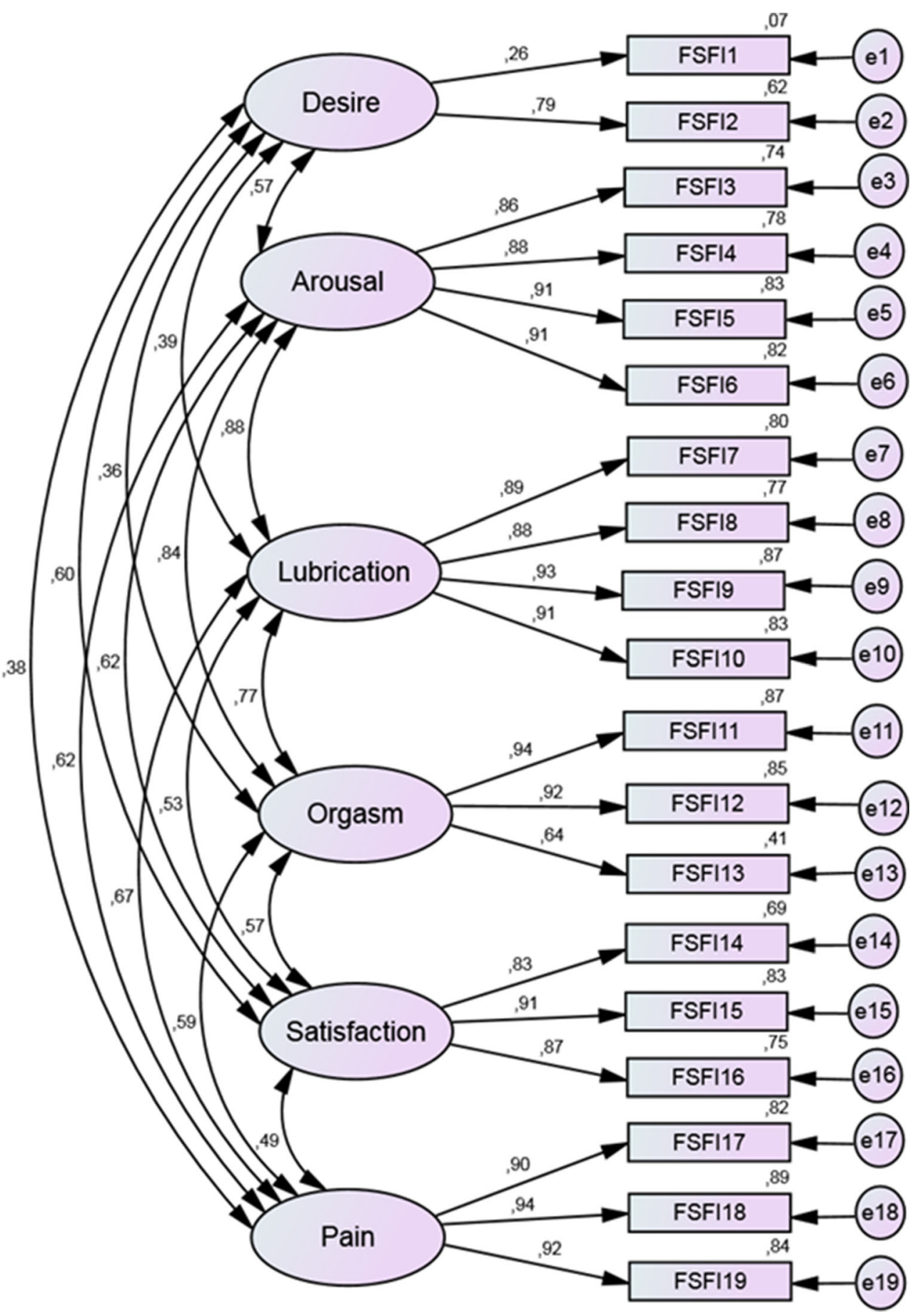

\section{Test-retest reliability}

To compare two clinical measurements, we applied Bland-Altman plots. The values randomly fluctuated around the mean difference $\pm 1.96 \mathrm{SD}$ (Fig. 2) in all domains. The test-retest reliability also showed strong and significant correlations between the domain and the fullscale scores (Spearman's rho $0.490-0.903, p<0.001$ ) (Table 3).

\section{Discussion}

The FSFI is one of the most widely used and reliable questionnaires regarding sexual functioning in the female population. It has been translated and validated in about 30 languages and is used to assess FSD in women with different medical conditions, including vulvodynia, chronic pelvic pain, vulvar intraepithelial neoplasia, breast cancer and urinary incontinence [21-25]. The present study results demonstrated a very 
Table 1 Mean values and Cronbach's $\alpha$ coefficients of the FSFI-H

\begin{tabular}{|c|c|c|c|c|c|}
\hline Domains & Score range & Factor & Mean \pm SD & Cronbach's alpha & Number of items \\
\hline Desire & $1.2-6.0^{\mathrm{a}}$ & 0.6 & $3.60 \pm 1.01$ & 0.423 & 2 \\
\hline 1. Frequency & $1.0-5.0$ & & $3.10 \pm 1.08$ & & \\
\hline 2. Level & $1.0-5.0$ & & $3.04 \pm 0.97$ & & \\
\hline Arousal & $0.0-6.0^{\mathrm{a}}$ & 0.3 & $4.02 \pm 1.946$ & 0.973 & 4 \\
\hline 3. Frequency & $0.0-5.0$ & & $3.62 \pm 1.73$ & & \\
\hline 4. Level & $0.0-5.0$ & & $3.19 \pm 1.50$ & & \\
\hline 5. Confidence & $0.0-5.0$ & & $3.40 \pm 1.61$ & & \\
\hline 6. Satisfaction & $0.0-5.0$ & & $3.58 \pm 1.72$ & & \\
\hline Lubrication & $0.0-6.0^{\mathrm{a}}$ & 0.3 & $4.60 \pm 2.11$ & 0.981 & 4 \\
\hline 7. Frequency & $0.0-5.0$ & & $3.85 \pm 1.78$ & & \\
\hline 8. Difficulty & $0.0-5.0$ & & $3.95 \pm 1.76$ & & \\
\hline 9. Frequency of maintaining & $0.0-5.0$ & & $3.86 \pm 1.73$ & & \\
\hline 10. Difficulty in maintaining & $0.0-5.0$ & & $4.05 \pm 1.75$ & & \\
\hline Orgasm & $0.0-6.0^{\mathrm{a}}$ & 0.4 & $4.28 \pm 2.03$ & 0.898 & 3 \\
\hline 11. Frequency & $0.0-5.0$ & & $3.65 \pm 1.78$ & & \\
\hline 12. Difficulty & $0.0-5.0$ & & $3.69 \pm 1.80$ & & \\
\hline 13. Satisfaction & $0.0-5.0$ & & $4.18 \pm 1.44$ & & \\
\hline Satisfaction & $1.2-6.0^{\mathrm{a}}$ & 0.4 & $4.28 \pm 1.46$ & 0.931 & 3 \\
\hline 14. With closeness with partner & $1.0-5.0$ & & $4.33 \pm 1.29$ & & \\
\hline 15. With sexual relationship & $1.0-5.0$ & & $4.27 \pm 1.34$ & & \\
\hline 16. With overall sex life & $1.0-5.0$ & & $3.98 \pm 1.45$ & & \\
\hline Pain & $0.0-6.0^{\mathrm{a}}$ & 0.4 & $4.46 \pm 2.12$ & 0.971 & 3 \\
\hline 17. Frequency during vaginal penetration & $0.0-5.0$ & & $3.77 \pm 1.79$ & & \\
\hline 18. Frequency following vaginal penetration & $0.0-5.0$ & & $3.79 \pm 1.78$ & & \\
\hline 19. Level during or following vaginal penetration & $0.0-5.0$ & & $3.86 \pm 1.72$ & & \\
\hline Full-scale score & $5.2-36.0^{\mathrm{b}}$ & & $25.25 \pm 9.27$ & 0.963 & 19 \\
\hline
\end{tabular}

$S D$ standard deviation

${ }^{a}$ The individual domain scores were calculated by adding the scores of the individual items that comprise the domain and multiplying the sum by the domain factor

${ }^{\mathrm{b}}$ The full-scale score is calculated by adding the six domain scores

high internal consistency since the Cronbach's alpha was 0.963 in the total scale. These high correlations are comparable to those reported by Rosen et al. in $2000(\geq 0.82)$.

Table 2 Discriminant validity of the FSFI-H

\begin{tabular}{lccr}
\hline & $\begin{array}{l}\text { General } \\
\text { Mean } \pm \text { SD }\end{array}$ & $\begin{array}{l}\text { POP } \\
\text { Mean } \pm \text { SD }\end{array}$ & $P$ value \\
\hline Desire & $3.604 \pm 1.007$ & $3.889 \pm 1.021$ & 0.087 \\
Arousal & $4.015 \pm 1.947$ & $2.868 \pm 1.023$ & 0.001 \\
Lubrication & $4.605 \pm 2.118$ & $1.976 \pm 0.981$ & 0.001 \\
Orgasm & $4.276 \pm 2.037$ & $2.612 \pm 1.24$ & 0.001 \\
Satisfaction & $4.279 \pm 1.459$ & $2.627 \pm 1.271$ & 0.001 \\
Pain & $4.468 \pm 2.13$ & $4.808 \pm 1.449$ & 0.887 \\
FSFI & $25.246 \pm 9.268$ & $16.155 \pm 3.449$ & $<0.01$ \\
\hline
\end{tabular}

Data were calculated with Mann-Whitney U-test

$P O P$ Pelvic organ Prolapse, SD standard deviation
Furthermore, we also found a high level of test-retest reliability with a Pearson product-moment correlation coefficient of 0.992 in the control population. During the test-retest reliability analysis, the translation was found to be very appropriate; the test-retest reliability showed significant correlation between domains and full-scale scores. Our CFA results showed an acceptable fit to the six-factor model frequently found in previous validation studies. All fit indices were in the acceptable range, indicating that the FSFI-H can measure the same domains as the original questionnaire. By collecting data from over 300 participants, we managed to examine both pre- and postmenopausal women. The applicability of the desire factor needs to be examined in a further study because the present study did not exclude participants who had difficulties with the desire caused by sexually related personal distress, hypoactive desire disorders, etc., due to the lack of sexologists in the research group. Nevertheless, we must also consider the possibility of cultural differences $[26,27]$. Based on the results 

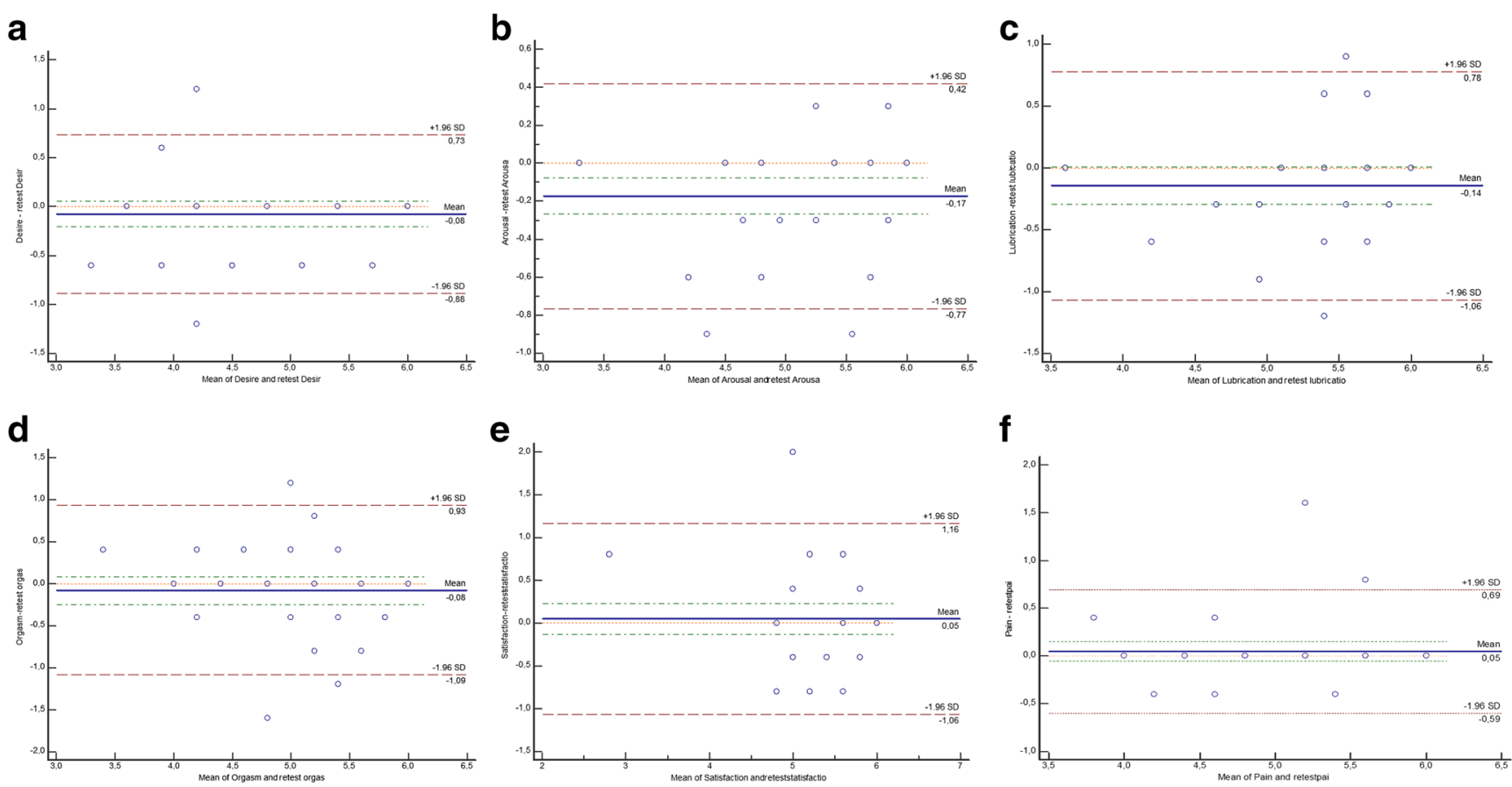

Fig. 2 To compare two clinical measurements (test-retest), we used Bland-Altman plots. The mean values ranged between -0.17 and 0.05 , where (a) represents desire, (b) arousal, (c) lubrication, (d) orgasm, (e) and in all domains values fluctuated randomly between mean $\pm 1.96 \mathrm{SD}$, satisfaction and (f) pain subscales

of the discriminant validity analysis, which included women with pelvic organ prolapse and demonstrated considerably lower total scores compared with healthy participants, it is assumed that the FSFI-H would be applicable to detecting sexual dysfunction as well.

\section{Strengths and limitation}

The strength of our study was the relatively high number of participants and the high Cronbach's alpha values. However, this study has several limitations. First, our study population failed to represent the average Hungarian female population, since the majority of the respondents were highly educated women living exclusively in urban areas. Our assumption is that this may have an effect on the respondents of the current study, who might be more open toward sexual issues compared with the average Hungarian woman. A further limitation of the study is that no concurrent validity was applied to obtain the cutoff point of the FSFI-H, unlike in other studies [28]. Finally, the results have a good statistical quality for confirming the linguistic validation, but they cannot fully

Table 3 Results of the FSFI-H test-retest reliability

\begin{tabular}{|c|c|c|c|c|c|}
\hline Domain & Phase & Mean & SD & Spearman rank correlation & $P$ value \\
\hline Desire & $\begin{array}{l}\text { Test } \\
\text { Retest }\end{array}$ & $\begin{array}{l}4.485 \\
4.560\end{array}$ & $\begin{array}{l}0.744 \\
0.778\end{array}$ & 0.851 & $<0.001$ \\
\hline Arousal & $\begin{array}{l}\text { Test } \\
\text { Retest }\end{array}$ & $\begin{array}{l}5.063 \\
5.235\end{array}$ & $\begin{array}{l}0.656 \\
0.596\end{array}$ & 0.884 & $<0.001$ \\
\hline Lubrication & $\begin{array}{l}\text { Test } \\
\text { Retest }\end{array}$ & $\begin{array}{l}5.490 \\
5.633\end{array}$ & $\begin{array}{l}0.627 \\
0.534\end{array}$ & 0.540 & $<0.001$ \\
\hline Orgasm & $\begin{array}{l}\text { Test } \\
\text { Retest }\end{array}$ & $\begin{array}{l}5.190 \\
5.270\end{array}$ & $\begin{array}{l}0.669 \\
0.730\end{array}$ & 0.704 & $<0.001$ \\
\hline Satisfaction & $\begin{array}{l}\text { Test } \\
\text { Retest }\end{array}$ & $\begin{array}{l}5.530 \\
5.480\end{array}$ & $\begin{array}{l}0.579 \\
0.709\end{array}$ & 0.490 & 0.001 \\
\hline Pain & $\begin{array}{l}\text { Test } \\
\text { Retest }\end{array}$ & $\begin{array}{l}4.950 \\
4.900\end{array}$ & $\begin{array}{l}0.767 \\
0.751\end{array}$ & 0.903 & $<0.001$ \\
\hline Total scale & $\begin{array}{l}\text { Test } \\
\text { Retest }\end{array}$ & $\begin{array}{l}30.708 \\
31.078\end{array}$ & $\begin{array}{l}2.185 \\
2.248\end{array}$ & 0.848 & $<0.001$ \\
\hline
\end{tabular}


confirm the psychometric properties of the FSFI. Despite these limitations, the authors believe that the FSFI-H is a valid and reliable instrument that can be used in settings to measure sexual functioning in Hungarian women who are in relationships and have no serious diseases that could influence their sexual activity.

\section{Conclusion}

In our current study, we successfully translated and adapted the FSFI questionnaire into the Hungarian language (FSFI-H can be found in the Appendix).

Acknowledgements We thank the medical assistants and nurses working at the University of Pecs, Department of Obstetrics and Gynecology, Pecs, Hungary, for their help and dedicated contributions toward the study and our patients. We also thank Prof. Dr. Miklos Koppan for his support, helpful comments and discussion.

Funding Information Open access funding provided by University of Pécs (PTE).

\section{Compliance with ethical standards}

Conflicts of interest The corresponding author has multiple affiliations and has received financial support from the Hungarian Academy of Sciences (MTA), Budapest, Hungary. The remaining authors report no conflicts of interest with the present study.

\section{Appendix}

\section{FSFI-H}

\section{Női szexuális funkció index kérdőív}

(Hungarian Version of Female Sexual Function Index, FSFI-H)

Kérjük, válaszoljon a következö kérdésekre, olyan egyértelmüen amennyire csak lehetséges. Válaszait teljes mértékben bizalmasan kezeljük!

A lent található kérdések az elmúlt 4 hetes időszakra vonatkoznak. Kérjük, hogy egy kérdésre egy választ adjon meg.

E kérdések megválaszolásakor a következő fogalom meghatározások érvényesek:

- A szexuális tevékenység magába foglalja a simogatást, előjátékot, maszturbációt és hüvelyi kapcsolatot.

- A szexuális közösülés: a férfi nemi szerv hüvelyi behatolása.

- A szexuális stimuláció magában foglalja a partnerrel való előjátékot, az önstimulációt (maszturbáció) vagy a szexuális fantáziát.

- A szexuális vágy vagy érdeklődés olyan érzés, amely magában foglalja azt, hogy szexuális élményt szeretne, fogékony a partner szexuális kezdeményezésére, gondolkodik vagy fantáziál a szexről.

- A szexuális izgalom olyan érzés, amely magában foglalja a szexuális izgalom fizikai és szellemi aspektusait, a nemi szervek melegségének vagy bizsergésének érzését, a nedvesedést, esetleg izom összehúzódásokat. 
K1. Az elmúlt 4 hétben milyen gyakran érzett szexuális vágyat, vagy érdeklődést?

$\square \quad$ Majdnem mindig, vagy mindig

$\square \quad$ Gyakran (az adott időszak több mint felében)

$\square \quad$ Néha (körülbelül az adott időszak felében)

$\square \quad$ Ritkán (az adott időszak kevesebb, mint felében)

$\square$ Majdnem soha, vagy soha

K2. Az elmúlt 4 hétben hogyan értékelné a szexuális vágyának, vagy érdeklődésének a szintjét?

$\square \quad$ Nagyon magas

$\square \quad$ Magas

$\square \quad$ Közepes

$\square \quad$ Alacsony

$\square \quad$ Nagyon alacsony, vagy semmilyen

K3. Az elmúlt 4 hétben milyen gyakran érzett szexuális izgalmat nemi aktus, vagy egyéb szexuális tevékenység közben?

$\square \quad$ Nem volt szexuálisan aktív

$\square \quad$ Majdnem mindig, vagy mindig

$\square \quad$ Gyakran (az adott időszak több mint felében)

口 Néha (körülbelül az adott időszak felében)

$\square \quad$ Ritkán (az adott időszak kevesebb, mint felében)

$\square \quad$ Majdnem soha, vagy soha

K4. Az elmúlt 4 hétben milyennek értékelné szexuális izgalmát nemi aktus, vagy egyéb szexuális tevékenység közben?

$\square \quad$ Nem volt szexuálisan aktív

$\square \quad$ Nagyon magas

$\square$ Magas

Mérsékelt

$\square \quad$ Alacsony

$\square \quad$ Nagyon alacsony, vagy semmilyen

K5. Az elmúlt 4 hétben mennyire volt biztos abban, hogy a nemi aktus, vagy egyéb szexuális aktivitás közben szexuális izgalmat fog érezni?

$\square \quad$ Nem volt szexuálisan aktív

$\square \quad$ Nagyon biztos voltam benne

$\square$ Biztos voltam benne

Mérsékelten voltam biztos benne

$\square \quad$ Alig voltam biztos benne

$\square \quad$ Egyáltalán nem voltam biztos benne, nem hittem benne 
K6. Az elmúlt 4 hétben milyen gyakran volt elégedett szexuális izgalmának szintjével nemi aktus, vagy egyéb szexuális aktivitás során?

$\square \quad$ Nem volt szexuálisan aktív

$\square \quad$ Majdnem mindig, vagy mindig

$\square \quad$ Az esetek többségében (az esetek több mint a felében)

$\square \quad$ Néha (körülbelül az estek felében)

$\square \quad$ Ritkán (az esetek kevesebb, mint felében)

$\square \quad$ Majdnem soha, vagy soha

K7. Az elmúlt 4 hétben milyen gyakran vált síkossá ("nedvessé”) nemi aktus, vagy egyéb szexuális aktivitás során?

$\square \quad$ Nem volt szexuálisan aktív

$\square \quad$ Majdnem mindig, vagy mindig

$\square \quad$ Az esetek többségében (az esetek több mint a felében)

$\square \quad$ Néha (körülbelül az estek felében)

$\square \quad$ Ritkán (az esetek kevesebb, mint felében)

$\square \quad$ Majdnem soha, vagy soha

K8. Az elmúlt 4 hétben mennyire volt nehéz síkossá ("nedvessé") válnia?

$\square \quad$ Nem volt szexuálisan aktív

$\square \quad$ Rendkívül nehezemre esett, vagy nem sikerült

$\square \quad$ Nagyon nehezemre esett

$\square \quad$ Nehezemre esett

$\square \quad$ Kissé esett nehezemre

$\square \quad$ Nem esett nehezemre

K9. Az elmúlt 4 hétben milyen gyakran sikerült megmaradnia síkosnak ("nedvesnek") a nemi aktus, vagy az egyéb szexuális aktivitás végéig?

$\square \quad$ Nem volt szexuálisan aktív

$\square \quad$ Majdnem mindig, vagy mindig

$\square \quad$ Az esetek többségében (az esetek több mint a felében)

$\square \quad$ Néha (körülbelül az estek felében)

Ritkán (az esetek kevesebb, mint felében)

$\square \quad$ Majdnem soha, vagy soha

K10. Az elmúlt 4 hétben mennyire esett nehezére a síkosság ("nedvesség") fenntartása a nemi aktus, vagy az egyéb szexuális aktivitás végéig?

$\square \quad$ Nem volt szexuálisan aktív

$\square \quad$ Rendkívül nehezemre esett, vagy nem sikerült

$\square \quad$ Nagyon nehezemre esett

$\square \quad$ Nehezemre esett

$\square \quad$ Kissé nehezemre esett

$\square \quad$ Nem esett nehezemre 
K11. Az elmúlt 4 hétben nemi aktus, vagy egyéb szexuális ingerlés során milyen gyakran volt orgazmusa?

$\square \quad$ Nem volt szexuálisan aktív

$\square \quad$ Majdnem mindig, vagy mindig

$\square \quad$ Az esetek többségében (az esetek több mint a felében)

$\square \quad$ Néha (körülbelül az estek felében)

$\square \quad$ Ritkán (az esetek kevesebb, mint felében)

$\square \quad$ Majdnem soha, vagy soha

K12. Az elmúlt 4 hétben nemi aktus, vagy egyéb szexuális ingerlés során mennyire volt nehéz az orgazmus elérése?

$\square \quad$ Nem volt szexuálisan aktív

$\square \quad$ Rendkívül nehezemre esett, vagy nem sikerült

$\square \quad$ Nagyon nehezemre esett

$\square \quad$ Nehezemre esett

$\square \quad$ Kissé nehezemre esett

$\square \quad$ Nem esett nehezemre

K13-16. Az alábbiakban felsorolt minden állításra jelölje meg mennyire volt megelégedve

$\square$ Nem volt szexuálisan aktív

\begin{tabular}{|c|c|}
\hline $\begin{array}{l}\text { Nagyon } \\
\text { Elégedett }\end{array}$ & $\begin{array}{l}\text { Inkább } \\
\text { elégedett }\end{array}$ \\
\hline
\end{tabular}

13. az orgazmust elérő

képességével nemi aktus, vagy

egyéb szexuális aktivitás során?

14. a párja és Ön közötti érzelmi közelséggel szexuális együttlétük során?

15. szexuális kapcsolatával partnerével?

16. nemi életével általában? 
K17. Az elmúlt 4 hétben milyen gyakran volt kellemetlen illetve fájdalmas a hüvelyi behatolás?

Nem próbált meg közösülni

$\square \quad$ Majdnem mindig, vagy mindig

$\square \quad$ Az esetek többségében (az esetek több mint a felében)

$\square \quad$ Néha (körülbelül az estek felében)

$\square \quad$ Ritkán (az esetek kevesebb, mint felében)

$\square \quad$ Majdnem soha, vagy soha

K18. Az elmúlt 4 hétben milyen gyakran érzett kellemetlenséget, vagy fájdalmat hüvelyi behatolást követően?

Nem próbált meg közösülni

Majdnem mindig, vagy mindig

$\square \quad$ Az esetek többségében (az esetek több mint a felében)

$\square \quad$ Néha (körülbelül az estek felében)

$\square \quad$ Ritkán (az esetek kevesebb, mint felében)

$\square \quad$ Majdnem soha, vagy soha

K19. Az elmúlt 4 hétben hogyan értékelné a kellemetlenség, vagy a fájdalom szintjét hüvelyi behatolás közben, vagy azt követően?

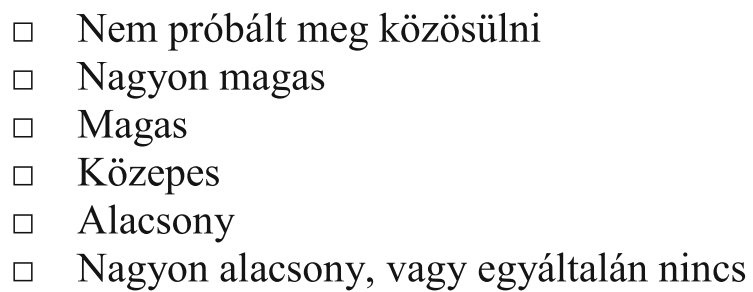

Név/jelszó/más azonosító:

Open Access This article is distributed under the terms of the Creative Commons Attribution 4.0 International License (http:// creativecommons.org/licenses/by/4.0/), which permits unrestricted use, distribution, and reproduction in any medium, provided you give appropriate credit to the original author(s) and the source, provide a link to the Creative Commons license, and indicate if changes were made.

\section{References}

1. McCabe MP, Sharlip ID, Lewis R, et al. Risk factors for sexual dysfunction among women and men: a consensus statement from the fourth International Consultation on Sexual Medicine. J Sex Med. 2016;13:153-67.

2. Laumann EO, Nicolosi A, Glasser DB, Paik A, Gingell C, Moreira E, et al. Sexual problems among women and men aged 40-80 y: prevalence and correlates identified in the global study of sexual attitudes and behaviors. Int J Impot Res. 2005;17:39-57.

3. Laumann EO, Glasser DB, Neves RC, Moreira ED, GSSAB Investigators' Group. A population-based survey of sexual activity, sexual problems and associated help-seeking behavior patterns in mature adults in the United States of America. Int J Impot Res. 2009;21:171-8.

4. Lewis RW, Fugl-Meyer KS, Corona G, et al. Definitions/epidemiology/risk factors for sexual dysfunction. J Sex Med. 2010;7:1598607.

5. Laumann EO, Waite LJ. Sexual dysfunction among older adults: prevalence and risk factors from a nationally representative US probability sample of men and women 57-85 years of age. J Sex Med. 2008;5:2300-11.

6. Ferenidou F, Kapoteli V, Moisidis K, et al. Presence of a sexual problem may not affect women's satisfaction from their sexual function. J Sex Med. 2008;5:631-9. 
7. Hayes RD, Dennerstein L, Bennett CM, Fairley CK. What is the "true" prevalence of female sexual dysfunctions and does the way we assess these conditions have an impact? J Sex Med. 2008;4: 777-87.

8. Kommentár SP. Szülészet Nőgyógy Továbbkép Sz. 2009;2:69-70.

9. Rosen R, Brown C, Heiman J, et al. The female sexual function index (FSFI): a multidimensional self-report instrument for the assessment of female sexual function. J Sex Marital Ther. 2000;26: 191-208.

10. Wiegel M, Meston C, Rosen R. The female sexual function index (FSFI): cross-validation and development of clinical cutoff scores. J Sex Marital Ther. 2005;31:1-20.

11. Waren JE, Sherbourne CD. The MOS-36 item short form health survey (SF-36). I. Conceptual framework and item selection. Med Care. 1992;30:473-83.

12. McHorney CA, Ware JE, Raczek AE. The MOS 36-item short-form health survey (SF-36): II. Psychometric and clinical tests of validity in measuring physical and mental health construct. Med Care. 1993;31:247-63.

13. Hays RD, Sherbourne CD, Mazel RM. The RAND 36-item health survey 1.0. Health Econ. 1993;2(3):217-27.

14. Czimbalmos A, Nagy Z, Varga Z, Husztik P. Páciens megelégedettségi vizsgálat SF-36 kérdőívvel, a magyarországi normál értékek meghatározása. Népegészségügy. 1999;1:4-19.

15. Acquadro C, Kopp Z, Coyne KS, et al. Translating overactive bladder questionnaires in 14 languages. Urology. 2006;67(3):536-40.

16. Kammerer-Doak D. Assessment of sexual function in women with pelvic floor dysfunction. Int Urogynecol J Pelvic Floor Dysfunct. 2009;20(Suppl 1):S45-50. https://doi.org/10.1007/s00192-0090832-y.

17. Haylen BT, Maher CF, Barber MD, Camargo S, Dandolu V, et al. An International Urogynecological Association (IUGA)/ International Continence Society (ICS) joint report on the terminology for female pelvic organ prolapse (POP). Int Urogynecol J. 2016;27(2):165-94. https://doi.org/10.1007/s00192-015-2932-1.

18. $\mathrm{Hu} \mathrm{L}$, Bentler PM. Cutoff criteria for fit indexes in covariance structure analysis: conventional criteria versus new alternatives. Struct Equ Model. 1999;6:1-55.

19. Vrieze SI. Model selection and psychological theory: a discussion of the differences between the Akaike information criterion (AIC) and the Bayesian information criterion (BIC). Psychol Methods. 2012;17(2):228-43.

20. Beaton DE, Bombardier C, Guillemin F, Ferraz MB. Guidelines for the process of cross-cultural adaptation of self-report measures. Spine. 2000;25(24):3186-91.

21. Bartula I, Sherman KA. The female sexual functioning index (FSFI): evaluation of acceptability, reliability, and validity in women with breast cancer. Support Care Cancer. 2015;23(9):2633-41.

22. Baser RE, Li Y, Carter J. Psychometric validation of the female sexual function index (FSFI) in cancer survivors. Cancer. 2012;118:4606-18.

23. Verit FF, Verit A. Validation of the female sexual function index in women with chronic pelvic pain. J Sex Med. 2007;4:1635-41.

24. Filocamo MT, Serati M, Frumenzio E, et al. The impact of midurethral slings for the treatment of urodynamic stress incontinence on female sexual function: a multicenter prospective study. J Sex Med. 2011;8:2002-8.

25. Masheb RM, Lozano-Blanco C, Kohorn EI, et al. Assessing sexual function and dyspareunia with the female sexual function index (FSFI) in women with vulvodynia. J Sex Marital Ther. 2004;30: 315-24.

26. Roslan NS, Jaafar NRN, Sidi H, et al. The bio-psycho-social dimension of women's sexual desire: 'argumentum ad novitatem. Curr Drug Targets. 2017. https://doi.org/10.2174/ 138945011866617062209033.

27. Sun X, Li C, Jin L, et al. Development and validation of Chinese version of female sexual function index in a Chinese population- $-\mathrm{a}$ pilot study. J Sex Med. 2011;8:1101-11. https://doi.org/10.1111/j. 1743-6109.2010.02171.x.

28. Sidi H, Naing L, Midin M, et al. The female sexual response cycle: do Malaysian women conform to the circular model? J Sex Med. 2008;5:12359-8.

Publisher's note Springer Nature remains neutral with regard to jurisdictional claims in published maps and institutional affiliations. 